\title{
AMERIKAANSE STEMMEN OVER DE CONTROLLER'S FUNCTIE
}

\author{
door Prof. Dr H. J. van der Schroeff
}

$\mathrm{Na}$ de artikelen in het Mei- en Juninummer van de vorige jaargang van ons blad, waarin ik een pleidooi hield voor de invoering van de controller's functie en waarin ik trachtte de betekenis van deze functie voor de organisatie van het bedrijf in het licht te stellen, kan het wellicht zijn nut hebben eens een aantal uitspraken van vooraanstaande Amerikaanse deskundigen naar voren te brengen. De aanleiding daartoe zijn de beschouwingen, die Dr Adolph Matz, associate professor van de University of Pennsylvania, in verschillende in ons land gehouden redevoeringen aan de functie wijdde. Ter voorlichting van de lezers zij medegedeeld, dat Dr Matz enige tijd als specialist van de F.O.A. (Foreign Operation Administration te Parijs) in ons land heeft vertoefd voor het geven van adviezen terzake van hetgeen in ons land zou kunnen worden gedaan ter verhoging van de efficiëntie in het bedrijfsleven. Naar het oordeel van deze deskundige zou het invoeren van de controller's functie daartoe in hoge mate kunnen bijdragen. $Z$ ijn visie dienaangaande vindt men neergelegd in een voor de F.O.A. geschreven rapport, dat de titel draagt van .The functions of the Controller". In dit rapport, waarop wij gaarne de aandacht vestigen, zijn een aantal uitspraken van bekende Amerikaanse deskundigen opgenomen, welke zulk een treffend beeld geven van de betekenis, die in Amerikaanse leiderskringen aan de controller's functie wordt toegekend, dat zij de moeite van het vermelden waard zijn.

Een typerende uitlating, afkomstig van Frank $M$. Surface van de Standard Oil Company of New Jersey, waarmede de controller's functie op een originele Amerikaanse wijze is gekarakteriseerd, is de volgende:

,The controller is the provider of measures of performance to management. Management sets the destination, the road to travel and the method of travel. The controller translates the journey into miles per day, and then clocks each member of the team. The controller also keeps a running log of the trip and periodically culls from this infinite detail of his log the significant facts which enable management to assess the progress made by the team. He does not make out the master plan of action. He does not prescribe the methods of accomplishing the plan. He does express the complex functioning of modern business in its only common denominator, the language of figures".

In deze beeldspraak is de controller's functie op treffende wijze weergegeven, met name is de verhouding van de controller tot de overige functionarissen van het bedrijf, waaromtrent nog zoveel misverstand voorkomt, juist geschetst. Er blijkt nog eens duidelijk uit, dat de controller niet zelf het bedrijfsplan en de budgetten opstelt. Zulks zou ten enenmale onjuist zijn, omdat op deze wijze een kruising van bevoegdheden zou ontstaan, welke in hoge mate schadelijk zou zijn voor de gezagsverhoudingen. De medewerking van de controller bij de opstelling van de budgetten bepaalt zich tot het geven van steun en voorlichting aan de functionarissen in de verschillende ",lijnen", die budgetaire verantwoordelijkheid dragen. Deze steun betreft in de eerste plaats het verstrekken van de gegevens. met behulp waarvan de budgetten moeten worden opgebouwd, over welke gegevens de controller beschikt vanuit het onder zijn leiding staande 
administratieve apparaat. $\mathrm{Hij}_{\mathrm{ij}}$ geeft bovendien de voorlichting omtrent het hanteren van de cijfers, omdat hij als deskundige beter dan wie ook de taal van de cijfers verstaat. De functie is raak getypeerd in de laatste zinsnede van het citaat, waarin wordt gezegd, dat deze daarin bestaat ,to express the complex functioning of modern business in its only common denominator, the language of figures". De controller geeft zijn voorlichting aan het bedrijf van hoog tot laag; met zijn medewerkers voorziet hij alle functionarissen die daarvoor in aanmerking komen van de gegevens, welke zij voor hun werk en hun beslissingen behoeven. Zo kon $\mathrm{ik}$ in het rapport, waarin ik mijn ervaringen omtrent mijn Amerikaanse studiereis neerlegde (C.O.P. „Organisatiemethoden en Efficiëntie-controle in Amerikaanse Bedrijven") schrijven, dat het opvallend is welke ruime informatie aan de functionarissen van het bedrijf - de leidende in het bizonder, waaronder de bazen - wordt verstrekt over dat deel van de uitvoering, waarvoor zij verantwoordelijk zijn. Ook de snelle voorlichting welke de administratie aan topleiding, subalterne leiding en de onderscheiden delen van de uitvoering weet te geven, is opmerkelijk. Dat bij deze voorlichting eenvoud en snelheid boven comptabele accuratesse en volledigheid wordt geprefereerd, is een punt van belang waarop ik reeds vroeger de aandacht heb gevestigd. Dit hele gebied van informatie, rapportering en interpretatie is het onbetwiste terrein van de controller. Aan dit werk ontleent hij voor een belangrijk deel zijn betekenis voor het bedrijf.

Een andere uitspraak, welke eveneens voor de inhoud van de controller's functie karakteristiek kan worden genoemd, is die van Frank J. Carr, de eerste president van het Controllers Institute of America:

,There is perhaps no single position in industry which offers a greater opportunity for constructive service than the controller's. He can exercise a definite influence over the operating results of his own concern. He can be helpful to business by giving sound and constructive advice to legislative bodies, regulatory bodies and other government agencies. He can help promote sound economic thinking and can take a significant part in leading business out of the maze of difficulties through which it is now going. Finally, the position offers a tremendous opportunity to the individual himself because it can develop into as important an element in business and society as any of the great professions".

In deze functie-omschrijving wordt vooral de staffunctie beklemtoond en na het bovenstaande zal het reeds duidelijk zijn geworden, dat dit stafadvies niet alleen de topleiding betreft, maar alle organen in het bedrijf, die bij de uitvoering van hun taak voorlichting behoeven. Vergeleken bij de thans fungerende administratieve leiders is het nieuwe element in de controller's functie gelegen in de interpretatie en de analyse van de gegevens, waartoe de administratie voert. Op grond van deze analyse geeft de controller zijn adviezen ook aan de lagere functionarissen, de bazen daarbij niet te vergeten. De wijze waarop deze omtrent de resultaten van het deel van de uitvoering, dat aan hun leiding is onderworpen, worden voorgelicht, heeft er ongetwijfeld toe bijgedragen hen voor hun werk te interesseren en hun het kostenbesef bij te brengen, dat een ieder, die in de gelegenheid is geweest persoonlijk van het Amerikaanse bedrijfsleven kennis te nemen, zal hebben getroffen.

Eén van de beste definities van de controller's functie is wel die, ge- 
geven door C. E. Knoeppel in een rede voor de Chicago Conferentie van het Controller's Institute in 1935, waarin werd gezegd:

"We can define controllership as the coordinating function in a business, working in a detached and unbiased way, and charged with the responsibility of planning for profits and providing suitable profit control machinery. It is the investigative, analytical, suggestive, and advising function, studying the business at all points all the time, and formulating what the proposed practice should be with reference to sales and production control as well as financial control, which, when accepted or modified by the executive management, becomes the approved practice for use by the performing or ",line" function".

Ook in deze functie-omschrijving treedt het adviserende element sterk naar voren. De controller brengt zijn adviezen uit, welke, na door de hoogste leiding te zijn geautoriseerd, de richtlijnen voor de uitvoering vormen. In het citaat wil ik de aandacht vragen voor de uitdrukking, dat de functie moet worden vervuld ,in a detached and unbiased way". Een eerste eis voor de juiste vervulling van de functie is, dat de controller zich onbevangen en onbevooroordeeld stelt tegenover de problemen, welke hem worden voorgelegd en terzake waarvan zijn advies wordt gevraagd. In het debat, dat volgde op de voordracht welke ik op de regionale bijeenkomst van het Nederlands Instituut van Accountants te Arnhem hield, en waarin ik in het openbaar mijn pleidooi hield voor de invoering te onzent van de controller's functie, is de opmerking gemaakt (door de Heer Breek), dat ook voor de controller's functie de leer van het gewekte vertrouwen geldt. Ik wil deze opmerking overnemen, voor zover men deze bij wijze van woordspeling wil maken. Wat de leer van het gewekte vertrouwen inhoudt zal ik voor de lezers van dit blad niet behoeven toe te lichten. Deze leer geeft de norm voor de vervulling van de uitoefening van de functie van openbaar accountant in het maatschappelijk verkeer. Alleen in overdrachtelijke zin zal men een dergelijke norm voor de controller kunnen stellen en wel in die zin, dat men vertrouwen zal moeten stellen in de deskundigheid en de onbevangenheid van zijn oordeel. In dit opzicht kan men met een woordspeling de controller de „vertrouwens"man van het bedrijf noemen, waarmede deze term - naar duidelijk zal zijn - in een andere betekenis is gebruikt dan wanneer wij, gelijk wij gewend zijn te doen, spreken over de openbare accountant als vertrouwensman van het maatschappelijk verkeer.

Instructief mag ook de zienswijze worden genoemd van Walter $D$. Fuller, president van de Curtis Publishing Company en voordien controller van dit bedrijf:

.While I agree that the controller is the chief accounting officer, I regard him distinctly as a staff man and not a line man. The controller of my own company is a company officer, he can go into any department, ask any question, and make any study he wishes to. He must exercise reasonable tact, of course, and he does not have the executive power to compel obedience to his rulings, except among his own immediate subordinates. He accomplishes his results with the line executives through the respect in which his opinions are held by his associates ..... He is a specialist and acquires the facility in his work of such an expert".

Ook in deze formulering valt het op, dat de controller in de eerste plaats als een staffunctionaris wordt beschouwd. Behalve over zijn uitvoeringsapparaat, d.i. administratie, bezit de controller geen gezagsbe- 
voegdheden. $\mathrm{Hij}_{\mathrm{ij}}$ is de expert van het bedrijf op het gebied van administratieve, financiële en economische aangelegenheden. $\mathrm{Hij}_{\mathrm{ij}}$ verricht tevens de waarnemingen, waartoe het administratieve apparaat, dat hij bestuurt, hem in staat stelt.

Dr Matz onderscheidt in zijn geschrift de ,accounting”, „reporting" en ,assistance" functie van de controller. Van de rapporteringsfunctie zal men niet kunnen zeggen, dat deze nieuw voor Nederland is. Het verschil echter met het Amerikaanse bedrijfsleven bestaat daarin, dat de bemoeiingen van de controller met betrekking tot de rapportering omtrent de bedrijfsgang veel verder gaat. Naar algemene opvatting behoort het tot zijn taak de rapportering zodanig te verzorgen en te coördineren, dat alle functionarissen in het bedrijf, zowel leidende als uitvoerende, voorgelicht worden ten aanzien van de kritische gegevens, welke voor hun beleid en uitvoering gewenst zijn. In het kader van de rapporteringsfunctie valt ook te wijzen op het budget. In het merendeel van de bedrijven treedt de controller als ,,budget officer" op, of als voorzitter van het budgetcomité. De gegevens, waartoe de budgetverificatie (in ons land wordt ,budgetary control" veelal ten onrechte met budgetcontrole vertaald) leidt, worden door de controller ter kennis gebracht van de betrokken functionarissen, voorzien van een kritische analyse. Dr Matz wijst erop, hoezeer deze rapportering inzicht, tact en objectiviteit vereist.

Wij zullen niet in herhaling vervallen van hetgeen omtrent de ,assistance-function" wordt gezegd, welke met de beide andere genoemde ten nauwste samenhangt en deze completeert. De grote vlucht welke de controller's functie in het Amerikaanse bedrijfsleven heeft genomen, is grotendeels te danken aan de wijze, waarop de assistentie en adviserende functie zich heeft ontwikkeld. Het is op dit gebied, dat wij van het Amerikaanse bedrijfsleven veel kunnen leren. Om het met Dr Matz te zeggen: "The rise of the position of controller and the entire phase of controllership has been phenomenal in the United States. At this time practically all large corporations have recognized the need for the benefits that can be derived from maintaining a controller's department and combining its functions under the single executive. The past policy of dividing the duties among the other officers is rapidly disappearing". Met deze enkele woorden is de ontwikkelingsgang geschetst. Vooral de laatste, door mij gecursiveerde, zinsnede verdient bizondere aandacht. In de controller's functie is, behalve de administratieve coördinatie de financiële en economische beoordeling van het bedrijf in al zijn onderdelen en daarmede van het beleid en de uitvoering van zijn functionarissen, geconcentreerd. In dit deel van de functie ligt de evolutie van de controller's functie.

Met het bovenstaande is een bloemlezing gegeven van de meningen van een aantal belangrijke personen omtrent de controller's functie. De lezer moge het groot aantal citaten in het Engels, dat in het bovenstaande werd gegeven, verontschuldigen. Liever dan de oordelen in eigen woorden weer te geven heb ik de geciteerde deskundigen zelve aan het woord willen laten, om geen afbreuk te doen aan de markante wijze van typering van de functie. Deze citaten doen nog eens zien, hoe hoog de functie in het Amerikaanse bedrijfsleven wordt aangeslagen. De veel gehoorde uitspraak, die ieder Amerikaans deskundige zal willen bevestigen, dat de invoering van de controller's functie één van de belangrijkste verbeteringen vormt welke in de organisatie gedurende de laatste 20 jaren zijn in- 
gevoerd, moge het Nederlandse bedrijfsleven tot lering strekken. Als men in ons land het zover zal kunnen brengen, dat op de controller (hoe men deze functionaris bij ons ook zal willen noemen) dezelfde woorden van toepassing zijn als die voor het Amerikaanse bedrijfsleven gelden: „the controller and his work are not suffered, they are enjoyed", zal men daarmede een bijdrage hebben geleverd tot de activering van de administratie en een belangrijke schrede op de weg van de verbetering van de organisatie van het bedrijf hebben gezet. 